MONETARY ECONOMICS IN

DEVELOPING COUNTRIES 


\section{Monetary Economics in Developing Countries}

Second Edition

Subrata Ghatak

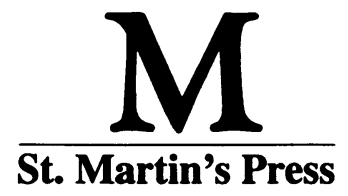


๑) Subrata Ghatak 1981, 1995

All rights reserved. No reproduction, copy or transmission of this publication may be made without written permission.

No paragraph of this publication may be reproduced, copied or transmitted save with written permission or in accordance with the provisions of the Copyright, Designs and Patents Act 1988, or under the terms of any licence permitting limited copying issued by the Copyright Licensing Agency, 90 Tottenham Court Road, London WIP 9HE.

Any person who does any unauthorised act in relation to this publication may be liable to criminal prosecution and civil claims for damages.

First edition 1981

Second edition 1995

Published in Great Britain by

MACMILLAN PRESS LTD

Houndmills, Basingstoke, Hampshire RG21 2XS

and London

Companies and representatives

throughout the world

A catalogue record for this book is available

from the British Library.

ISBN 978-0-333-57225-2 ISBN 978-1-349-23895-8 (eBook)

DOI 10.1007/978-1-349-23895-8

$\begin{array}{rrrrrrrrrr}10 & 9 & 8 & 7 & 6 & 5 & 4 & 3 & 2 & 1 \\ 04 & 03 & 02 & 01 & 00 & 99 & 98 & 97 & 96 & 95\end{array}$

Second edition first published in the United States of America 1995 by

Scholarly and Reference Division,

ST. MARTIN'S PRESS, INC.,

175 Fifth Avenue,

New York, N.Y. 10010

ISBN 978-0-312-12496-0

Library of Congress Cataloging-in-Publication Data

Ghatak, Subrata, 1939-

Monetary economics in developing countries / Subrata Ghatak.

p. $\mathrm{cm}$.

Includes bibliographical references and index.

ISBN 978-0-312-12496-0

1. Money-Developing countries. 2. Monetary policy-Developing

countries. I. Title.

HG1496.G44 1994

$332.4^{\prime} 91724-\mathrm{dc} 20$ 


\section{Contents}

Preface to the first edition $\quad$ ix

Preface to the second edition $\quad$ xi

Acknowledgements xii

Chapter 1 The role of money in a less developed country 1

1.1 Money in a barter economy 1

1.2 The definition of money: money and credit creation 2

1.3 Money markets in less developed countries (LDCs) 5

Chapter 2 The Keynesian and monetarist views on the importance of money $\quad 8$

2.1 The classical view $\quad 8$

2.2 The Keynesian theory 12

2.3 Money and the interest rate 16

2.4 A general equilibrium approach: the Hicksian IS-LM curves 18

2.5 Monetary and fiscal policy 21

2.6 The monetarists' case 22

2.7 Special characteristics of LDCs 24

2.8 Recent developments in the demand for money studies in LDCs

Appendix to Chapter 2: A2.1 35

Appendix to Chapter 2:A2.2: Demand for money in India:

1950-86: a cointegration analysis by Anita Ghatak

Chapter 3 The demand for money in LDCs: empirical results by (D. F. Deadman) 47

3.1 Conventional demand for money studies $\quad 47$

3.2 Stability testing of conventional demand for money studies 50

3.3 Error-correction models of demand for money functions for developing countries 53

Chapter 4 Monetary institutions in LDCs 63

4.1 The central bank: its functions in the LDCs 63

4.2 The commercial banks: the creation of bank deposits 65

4.3 The changing pattern of commercial banking in the LDCs 69

4.4 Rural money markets in LDCs 71

4.5 Currency boards in Africa 73 
Chapter 5 Theories of money and economic growth 75

5.1 A simple Harrod-Domar growth model 75

5.2 The neo-classical growth model $\quad 76$

5.3 Money in a neo-classical growth model: the Tobin model 78

5.4 Problems in the application of neo-classical monetary growth theory to LDCs

5.5 Economic growth and the role of financial intermediaries $\quad 84$

5.6 The Gurley-Shaw model $\quad 84$

5.7 Economic development and 'financial accumulation' $\quad 86$

5.8 Financial repression and economic growth: the McKinnon and Shaw model

Appendix to Chapter 5

Chapter 6 Money, inflation and growth (with Peter Ayre) 94

6.1 Characteristics of inflation in LDCs 94

6.2 The causes of inflation $\quad 96$

6.3 The effects of inflation on growth 103

6.4 Financial repression and the case against inflation 115

6.5 Major problems and policies for stabilisation in LDCs $\quad 118$

Appendix to Chapter 6: A model of inflation generation and stabilisation

Chapter 7 The Polak model: its application to the LDCs

7.1 The Polak-Boissonneult (PB) model 133

7.2 The application of the PB model 135

7.3 The PB model within the Keynesian income analysis $\quad 136$

7.4 The empirical results 137

7.5 Policy implications of the PB model 140

7.6 Limitations of the PB model 141

Chapter 8 Monetary policies in developing countries 143

8.1 Objectives of monetary policies in the LDCs 143

8.2 The theory of monetary policy 144

8.3 The instruments of monetary policy 148

8.4 The role of monetary policy in LDCs 155

Chapter 9 International liquidity, LDCs and Special Drawing Rights

9.1 The need for international monetary reserves 157

9.2 The exchange rate and the need for reserves 158

9.3 The Bretton Woods system and the dollar standard $\quad 159$

9.4 Problems of international liquidity 159

9.5 The nature and role of SDRs 162

9.6 The Extended Fund Facility $\quad 170$

9.7 The Trust Fund 171 
10.1 Unorganised money markets in LDCs and some consequences

10.2 Determination of rural rates in LDCs 179

10.3 An evaluation

10.4 Policies for an integrated development of rural financial markets in LDCs

10.5 Rural money markets and implications for monetary policy

Appendix to Chapter 10: Grameen Bank of Bangladesh

Chapter 11 The international debt crisis

11.1 LDC borrowing before 1973 195

11.2 Debt problems after $1973 \quad 196$

11.3 Benefits and costs of default theory 197

11.4 Application of the model to the debt crisis of $1982 \quad 199$

11.5 Managing the debt crisis 200

11.6 Policy responses to the debt crisis of $1982 \quad 202$

11.7 The International Monetary Fund (IMF), adjustment policies and LDCs 205

11.8 Criticisms of the IMF action 206

11.9 Response of the International Monetary Fund 206

11.10 New critiques of the International Monetary Fund 209

11.11 How effective are the International Monetary Fund programmes?

Appendix to Chapter 11 (with Paul Levine) 212

\section{Chapter 12 Exchange rate policies in developing countries}

12.1 The role and influence of exchange rates in the economy 224

12.2 Alternative exchange rate regimes 226

12.3 Exchange rate arrangements in developing countries 227

12.4 The choice of exchange rate regimes 231

12.5 The real target approach to exchange rate policy 235

12.6 The nominal anchor approach to exchange rate policy 237

12.7 Summary and conclusions $\quad 240$

$\begin{array}{ll}\text { References } & 243\end{array}$

Index 
For

Churni 


\section{Preface to the first edition}

This book is intended as an up-to-date undergraduate text for students taking a course on monetary economics in less-developed countries (LDCs). Since monetary economics is a vast subject, I had to be selective in my choice of topics. However, the important issues confronting the LDCs in the use of monetary and theory policy have been discussed carefully and rigorously. Some basic knowledge of micro- and macro- economics, elementary math-ematics and statistics has been assumed. A major aim of writing this book is to 'ease the constraint' on the supply of introductory textbooks on monetary economics in the LDCs. In this respect, I hope that this book may be useful. The text highlights some of the major areas of interest in current teaching and research in monetary economics in LDCs. After a brief introduction in which an attempt has been made to familiarise the readers with the special characteristics of the financial market and institutions in the LDCs, the focus of attention has been the theoretical contributions to the literature by the 'Keynesians' and the 'monetarists'. Next, the relevance of such theories to the LDCs has been discussed. Of particular interest to the readers could be the section on the empirical estimation of stability in the demand for money in the LDCs which has kindly been written by colleague Derek Deadman, to whom I remain very thankful. Chapter 3 describes the monetary institutions in the LDCs. However, given the availability of a significant amount of literature on the institutional side, no attempt has been made to discuss their activities in detail. In chapter 4 , the important relationship between money and economic growth has been discussed. Special emphasis has been given to the Tobin and McKinnon-Shaw models and the theory of financial repression in the LDCs. These models are then evaluated in the light of recent empirical findings. The scope of inflationary financing and growth in the LDCs has been the subject of thorough investigation in chapter 6. I am grateful to Peter Ayre who has kindly written this chapter with me. The Polak model and its empirical relevance to the LDCs has been the subject of careful analysis in chapter 6. Chapter 7 examines the role of monetary policy in the LDCs. The chapter on international liquidity and Special Drawing Rights has been written jointly by Peter Ayre and myself. I remain thankful to my colleague, Tony Jennings, who has kindly written the last chapter on the international monetary systems and the LDCs. He has indicated the need for international monetary reform in the 1980s, from the point of view of the LDCs, through the setting up of a new international economic order.

The issues raised in the book are mainly discussed within a framework of analytical economics. I am fully aware of the omissions that have taken place. 
However, I hope that the book will provide a concise and fairly comprehensive account of a number of key issues in monetary economics in the LDCs.

The book has been written during 1978 and 1979 while I have been teaching development economics at Leicester University. During the period of my writing, I have received constructive criticisms from many people. I am chiefly indebted to Peter Ayre, who has been kind enough to comment on various drafts of a number of chapters. I am also grateful to Michael Howard, Derek Deadman and Paul Herrington for their comments on different chapters. I also remain very thankful to Jeanne Cretney, Dorothy Logsdon, Joan Cook, Mavis Johnson, Heather Hopper and Janet Marks, for their skill and patience in typing the successive drafts of the manuscript. 


\section{Preface to the second edition}

The major objective in the second edition has been to achieve a reasonable balance between the recent monetary growth theories and policies and the realities of economic development in less developed countries (LDCs). Many chapters have been completely revised. Since readers may be particularly interested in understanding the basic concepts of the 'financial repression' and economic liberalisation, I have added a short section on the theories and applications of such concepts and their practical evaluations in LDCs. Chapters on 'Money, Inflation and Economic Growth and 'International Liquidity', originally with Peter Ayre, have been extensively revised in the light of of changes that occurred in the 1980s. New chapters on exchange rate policies and the debt crisis in LDCs have been added. The chapter on rural financial institutions and their role in macroeconomic stabilisation is also new. Sections on structural adjustments and financial liberalisation in the 1980s in many LDCS have been revised. A number of case studies have been discussed to analyse the relationship between money and prices in developing countries. To facilitate easy reading, I have relegated some technical and mathematical sections as appendices to the different chapters. Many new tables have been used to provide recent information of the recent events in the LDCs.

In the preparation of this edition, I am grateful to many colleagues and students. I am particularly grateful to Dr Anita Ghatak, Professor Paul Levine, Dr Kate Phylaktis, Ziggy MacDonald, Churni Ghatak, Nursen Albayrak and Steve Wheatley-Price for their help. I am also indebted to Stephen Rutt of Macmillan for his patience and excellent cooperation. 


\section{Acknowledgements}

The author and publishers wish to thank the following who have kindly given permission for the use of copyright material:

Chapman \& Hall and John Wiley, publishers of the journal Applied Economics and Journal of International Development, relatively.

International Monetary Fund for tables and graphs from Annual Report of the International Monetary Fund, 1978, and figures and tables from Finance and Development, September 1978, December 1978, July 1979.

McGraw-Hill Book Company for a diagram from Estimating Foreign Resource Needs for Economic Development, 1967, by J. Vanek.

Organisation for Economic Co-operation and Development for tables from The OECD Observer, Development Co-operation, 1977 Review, and Borrowing by Developing Countries on the Eurocurrency Market, 1977, by P. Wellons.

The World Bank for tables from Borrowing in International Capital Markets, and Private Direct Foreign Investment in Developing Countries: Policy Issues for Host and Home Governments and for International Institutions by K. Billerbeck and Y. Yasugi, World Bank Staff Working Paper No. 348, July 1979; World Bank, IMF, The Debt Tables, 1992-3, Washington, DC.

Every effort has been made to trace all the copyright-holders, but if any have been inadvertently overlooked the publishers will be pleased to make the necessary arrangement at the first opportunity. 